\title{
Foreign Terrorist Organization Designation, International Cooperation, and Terrorism ${ }^{1}$
}

\author{
Version accepted at International Interactions, 2018
}

Brian J. Phillips

University of Essex

\begin{abstract}
How does branding militant groups as "foreign terrorist organizations" affect them? Beyond its obvious policy importance, this question speaks to debates about counterterrorism, terrorism financing, and organizational dynamics of subnational violence. This article analyzes Foreign Terrorist Organization (FTO) designation, a key policy used by the U.S. government since 1997 to impose costs on foreign terrorist groups and those who might support them. Contrary to arguments that sanctions are ineffective and that terrorism is too "cheap" to be affected, it is argued that designation should weaken terrorist groups, reducing their attacks over time. However, the effect is probably conditional. FTO designation should be especially effective against groups operating in U.S.-aligned countries, given the importance of international cooperation in counterterrorism. Global quantitative analyses suggest that FTOs operating in U.S.-aligned countries carry out fewer attacks over time than other groups, taking many other factors into consideration.
\end{abstract}

\footnotetext{
${ }^{1}$ Previous versions of the manuscript were presented at APSA, ISA, and MPSA annual meetings, the University of Texas Austin, the University of Texas Dallas, and the University of Tennessee. The paper benefitted from discussion at these presentations. I thank Victor Asal, Jason Blazakis, Alex Braithwaite, Dan Byman, Ana Carolina Garriga, Aaron Hoffman, Todd Sandler, Jonathan Schanzer, and Dan Silverman for comments on the project. I thank Andrea Marín Serrano and Sandra Juan Delgado for research assistance. Funding acknowledgement: This research was supported by the Office of University Programs Science and Technology Directorate of the U.S. Department of Homeland Security through the Center for the Study of Terrorism and Behavior (CSTAB - Center Lead) Grant made to the START Consortium (Grant \# 2012-ST-61-CS0001). The views and conclusions contained in this document are those of the author and should not be interpreted as necessarily representing the official policies, either expressed or implied, of the U.S. Department of Homeland Security, or START.
} 
How does branding militant groups as "Foreign Terrorist Organizations" (FTOs) affect them? The U.S. government has applied this status to dozens of groups, but we know little about the effects of this action. FTO designation is a controversial instrument of U.S. counterterrorism efforts (e.g., Foust, 2012; Kessler, 2014). Other countries and international organizations employ similar lists, but the U.S. FTO list is the longest-lasting and probably the most influential. The listing imposes costs on groups, most notably economic sanctions. U.S. counterterrorism sanctions have frozen tens of millions of dollars from designated groups (U.S. Department of the Treasury, 2015), constrained their behavior by preventing further legal financial transactions, and led to the arrest of individuals providing material support to the organizations. FTO designation also provides a signal to the international community, which is a stigma that many groups seek to avoid. However, we do not know if these consequences translate into serious changes for terrorist organizations, such as a change in their violence output.

Some observers claim that FTO status can be "very effective" at weakening militant groups (Rekhi 2002) or that it is an "effective legal tool to impede terrorist organizations" (Schwartz 2014). The State Department asserts that the list plays a "critical role" in counterterrorism. ${ }^{1}$ However, others are skeptical. FTO designation "doesn’t matter much,” according to some analysts (Van Linschoten, Strick, and Kuehn 2012), and an anonymous White House official described FTO status as "largely symbolic" (DeYoung 2012). Writing about the broader approach the FTO list is part of, Neumann (2017a) argues that "the war on terrorist financing has failed." He suggests that states "waste time and money" trying to block funding to terrorist groups. Nevertheless, he acknowledges there is not enough research on the subject to know for sure (Neumann 2017b). 
FTO designation speaks to a number of debates in the literature. Scholars increasingly use terrorist organizations as the unit of analysis to understand terrorism and other violence (Asal, Schulzke, and Pate 2017; Jordan, 2014). Terrorist groups, like licit groups, face challenges connected to recruiting and bureaucratic organization (Crenshaw 1987). Research across multiple disciplines seeks to understand dynamics of terrorist group financing (Bantekis, 2003; Clarke 2015; Horgan and Taylor, 1999). Research on economic sanctions against states questions their effectiveness (Drezner, 1999). ${ }^{2}$ Some studies evaluate government tactics against militant groups, such as leadership removal (e.g., Johnston, 2012), but there is less analysis of other types of policies, and no systematic analysis of the effects of U.S. FTO designation on violence.

This article presents an argument that FTO designation can be associated with weakening terrorist organizations, but only for those groups that primarily operate in countries cooperating with the United States on security issues. This is because international partners are crucial to monitoring financing of local groups, enforcing sanctions, and assisting with direct action against groups (e.g., arrests) given U.S. intelligence. The argument and findings go against several common assumptions, such as the notion that terrorism is too "cheap" to depend on money, or that sanctions simply do not work. The findings also highlight the importance of international cooperation in counterterrorism efforts.

The next section discusses the FTO list, including designation criteria. It then discusses three important elements of the argument: that terrorist groups depend on money, sanctions can substantially affect terrorist group financing, and the effects of U.S. sanctions should be especially powerful against groups in U.S.-allied countries. The empirical section analyzes a sample of hundreds of terrorist groups. FTO status is associated with decreases 
in terrorist attacks over time, conditional upon the group operating in a country that is aligned with the United States. The conclusion presents suggestions for related research.

Terrorist group designation and its consequences

In 1997, the United States government created the Foreign Terrorist Organization list, initially designating 28 groups, such as Hezbollah, the PKK, and Colombia's National Liberation Army (Cronin, 2003). Other groups were added in subsequent years, including al Qaeda (1999), the Real Irish Republican Army (2001), and al Qaeda in Iraq (2004), which evolved into the Islamic State or ISIS. ${ }^{3}$ Designation indicates that financial institutions should seize all funds associated with the group and report them to the Department of the Treasury, and that the Department of Justice should prosecute U.S. citizens providing material support to the group. Additionally, members of the group can be expelled from or refused entry to the United States.

FTO status also has international implications. After the establishment of the U.S. FTO list, other states and institutions started their own similar lists. Scholars who analyzed six such lists describe the Unites States as a "trendsetter," exerting substantial influence on other countries' lists (Ilbiz and Curtis 2015). There is overlap across lists regarding which groups are included, although the U.S. list is more global, while other countries' lists are more regional (Freedman 2010). ${ }^{4}$

Another international implication of the FTO list is that other states can cite the designation to attempt to gain increased legitimacy for their counterterrorism actions. When Kashmiri group Hizbul Mujahideen was recently listed, for example, the Indian press claimed this was “an endorsement of India's narrative on Kashmir” (Roy Chaudhury 2017). India's ministry of foreign affairs commended the FTO designation in a press conference, 
and used the opportunity to describe the "terrorist activities" of the group - probably to the dismay of Pakistan, which opposed the designation (Al Jazeera 2017). In the Philippines in 2002, when the United States designated the New People's Army, local analysts argued that this would encourage their government to intensify its controversial counterinsurgency tactics (Conde 2002). When another Philippine group was designated an FTO, a Philippine government spokesperson claimed that this reaffirmed the government's ideas about the group, and that the designation recognized the government's "decisive action" thus far (Argullas 2018).

Groups must fit three criteria to be considered for designation. They need to be foreign to the United States, use terrorism, ${ }^{5}$ and threaten the security of U.S. nationals or national security of the United States. National security includes "national defense, foreign relations, or economic interests. ${ }^{, 6}$ While these criteria seem straightforward, the actual process to designate a group is complex, and involves numerous branches of the federal government - with multiple actors able to veto the potential designation. As a result, it is not the case that every foreign terrorist group that presents some threat to U.S. citizens or the country is on the list (Young, 2012).

There are diplomatic, bureaucratic, and domestic political considerations involved in the designation process. ${ }^{7}$ The FTO list is created and maintained by the State Department, but other U.S. government actors are involved. ${ }^{8}$ After State's Bureau of Counterterrorism identifies a potential designee, the Departments of Treasury and Justice are consulted, as well as geographic bureaus within State. Any of these actors can prevent a group from being designated. During this phase, various other actors provide input on the potential designee: the intelligence community, the National Security Council, the Department of Defense, and the Department of Homeland Security (U.S. Government 
Accountability Office, 2015: 21). Eventually, Congress is notified, and if there is no Congressional objection, the group enters the list.

The 2014 designation of Boko Haram is an example of the complex path to designation (Kessler, 2014). Members of Congress suggested considering FTO designation for the group in 2011, but the Nigerian government - and regional experts within the State Department - argued that designation could disrupt aid flows. There was also concern that designation could give the group desired international attention. The group was finally designated at the end of 2013. Other groups have entered the list much more quickly. However, the Boko Haram example illustrates the notion that designation often seems consistent with Allison's (1971) organizational process or government politics models of decision-making. It is not necessarily "national security," from a unitary actor standpoint, that alone determines which groups are on the list.

The Taliban is another complicated case. Despite technically meeting the criteria, the group never completed the designation process. Like the Boko Haram situation, the Afghan government and elements of the U.S. government were opposed, in this case because of the possibility of negotiations with the Taliban (e.g., Foust 2012). If the group were designated, such negotiations could be more complicated, if not illegal. Overall, these examples demonstrate that designation is a complicated process, leading to a diverse set of organizations on the list. One study found that groups that have attacked aviation targets, or have Islamist ideology, are especially likely to be designated FTOs (Beck and Miner 2013).

Once designated, groups remain on the FTO list until their status is revoked. Every five years, groups are reviewed to see if the circumstances regarding their listing particularly their capability and intentions - have changed. ${ }^{9}$ At this point, de-listing could occur. Alternately, the Secretary of State and Congress have the authority to revoke FTO 
status at any time (Cronin 2003). Of the 46 groups designated in the years examined in this study, most (33) are still FTOs today. As with the initial designation, political and bureaucratic disagreements can affect status revocation. For example, a great deal of lobbying and debate went into the eventual revocation Mujahedin-e-Khalq's FTO status. ${ }^{10}$

The U.S. government expends considerable resources on FTO designation and related enforcement because it is expected to put pressure on designated terrorist groups. Is that goal being achieved? How does FTO designation affect terrorism? The following sections presents a three-part argument, explaining how (1) terrorist groups depend on funding, and how (2) sanctions can affect funding, reducing groups' ability to attack. However, the effects are conditional on the country in which the group operates. (3) Harmful effects of designation are especially strong in countries aligned with the United States on counterterrorism, because cooperation is essential for designation to have meaningful consequences.

\section{Terrorist groups depend on funding}

Terrorist groups are sometimes thought of as poor, weak actors who scrape together a little cash to build cheap bombs. Terrorism is less expensive than conventional warfare, and terrorists are often relatively weak compared to their state adversaries (Crenshaw 1981), but terrorism still requires substantial resources. Levitt (2006: 52) discusses the extent to which Hamas depends on financial incentives for members. Beyond the direct material costs of an attack, which can be thousands of dollars, there are longer-term expenses such as monthly payments to the family of the "martyr." Such payments make it difficult to calculate the precise cost of attacks, but these incentives allow Hamas to keep its steady supply of recruits, and remain a prominent terrorist organization. 
Hamas stands out for its vast budget, but other groups also depend on funds to maintain their operational pace. Shapiro's (2013) in-depth research shows that terrorist organizations regularly pay their operatives, as a strategy to overcome the challenges of organizing terror (e.g., ibid: 108). Many of the groups he analyzes had internal disagreements about money, with examples coming from small leftist groups in Europe to the Mau Mau in Kenya (ibid: 73-74). Additionally, the tactic of paying families of "martyrs" is not exclusive to Islamist groups. The Irish Republican Army, for example, financially supported families of group members in prison (Horgan and Taylor, 1999). Terrorist groups of virtually every ideological goal and size depend on monetary resources. A substantial body of policy-oriented literature, as well as news reports, provides examples of the extent to which terrorist groups rely on money (e.g., Clarke, 2015; Jorisch, 2009). The United Self-Defense Forces Colombia (AUC), designated an FTO in 2001, extorted at least \$1.7 million from Chiquita Brands International between 1997 and 2004 (Jorisch, 2009: 14-15). A network of hawalas in Somalia apparently funneled millions of dollars to al Qaeda, also an FTO, in the early 2000s (ibid: 74-75). When al Qaeda wanted to fund an attack in Turkey, it sent $\$ 100,000$ in cash to operatives there. The resulting truck bombing, in Istanbul in 2003, killed 58 people (Vick, 2007).

Terrorist group funding is critical for terrorist attacks, and attacks are crucial for group survival. "The terrorists' ability to attract - and moreover, to continue to attract attention is most often predicated on the success of their attacks," argues Bruce Hoffman (2006: 248-249). Individual attacks can cost thousands of dollars, and organizations need funds beyond that amount to keep members loyal, to continue training, and to maintain operational security, among other expenses. Some groups spend a considerable amount of their funds on social services. This allows them to have especially loyal recruits and 
supporters, which ultimately helps the group to attack more and more lethally than other groups (Berman, 2009).

Attacks are central to terrorist groups' existence, but, attack rates vary considerably between groups and over time. ${ }^{11}$ Terrorist group attack rates decrease either voluntarily or involuntarily: the group might voluntarily decrease its violence as it regroups after resource depletion or other generally internal reasons, or it might be unable to maintain its previous attack rate because of imposed pressure such as successful counterterrorism (Becker, 2017). Constraints on a group's funding seem likely to lead to fewer attacks through both mechanisms.

\section{FTO status is likely to affect groups and their violence}

Given that terrorist groups depend on money, which makes attacks possible, can designation significantly affect terrorist groups? Substantial evidence suggests the affirmative. The U.S. Department of the Treasury reports that it has blocked almost $\$ 22$ million in funds from sanctioned terrorists, as of the end of 2014 (U.S. Department of the Treasury, 2015). Sanctioned terrorists include FTOs and their members, as well as individuals and groups named in Executive Orders, which generally overlap with the FTO list. ${ }^{12}$ Aside from the direct effects on groups of more than $\$ 20$ million in lost funds, the sanctions also affect organizations through making other actors afraid of doing business with the group. This forces organizations to become more secretive with their funding (which is costly in itself), and forces them to engage in riskier or potentially alienating fundraising activities such as the drug trade. Sanctions can affect groups based outside the United States because high-level members of groups often want U.S. bank accounts, and many groups have donors in the United States. 
Beyond financial effects, sanctions also have immigration status effects, forcing members out of the United States and barring their entry. Between 2009 and 2013, the United States denied 1,069 people non-immigrant visas, and 187 applicant immigrant visas, based on terrorist activity or affiliation with a designated FTO (Government Accountability Office 2015, 15-16). Additional individuals are stopped at ports of entry by U.S. Customs and Border Protection and denied admission to the United States because of an FTO affiliation (ibid., 16). This can hinder operational planning, fundraising, political outreach, and other group goals. For example, if a group is planning to attack inside the United States, the operation becomes more difficult if the group is not able to have members legally in the country. Many militant groups have or try to have operatives in the United States for fundraising from diaspora communities, or to lobby allies or potential allies in Washington. ${ }^{13}$ All of this becomes more challenging when group members are barred from the country. Overall, members of designated FTOs try to enter the United States, but are prevented from doing so - which is likely to affect a broad range of group activities.

Once sanctions begin against a group, not only are its current funds off-limits, but other actors might become hesitant about doing business with the group. This includes individual donors, banks, and charities that might funnel money to the group. The idea of "material support" goes beyond direct financial contributions. For example, a New York man who operated a satellite television business was providing customers access to a Hezbollah-controlled television channel. He was charged with providing material support to the FTO and was sentenced to more than five years in prison (Weiser, 2009). This probably discouraged other individuals from doing business with Hezbollah.

The "chilling effect" of FTO designation and related sanctions has led banks to change policies and increase their scrutiny of customers, making it harder for terrorists to 
use formal financial structures to hold or move money. Beyond banks, another example of changed behavior is that of Chiquita Brands International, which eventually stopped giving extortion money to the FTO-designated AUC, probably at least in part because of the court case which resulted in $\$ 25$ million in fines against the company by the U.S. government (Jorisch, 2009: 14-15).

The FTOs themselves also update their behavior as a response to sanctions. Changes include increased activity outside of formal financial institutions, including simply carrying large amounts of cash, and increasingly creative money laundering (Gilmore, 2011: 145149). However, these measures are not risk-free themselves. Governments sanction hawala systems, and cash bundles are frequently intercepted (Moran, 2014).

Sanctions can also pressure groups to move from funding via donations to more politically risky tactics such as the drug trade, kidnapping, and extortion. As political actors, some terrorist groups try to maintain a relative moral high ground, and often avoid such tactics (Freeman 2011, 468). In recent years, though, terrorist groups increasingly use kidnappings solely to raise funds. Some analysts attribute increased kidnapping to efforts against terrorism financing (Center for Security Studies, 2013: 2). The apparent shift in behavior of some groups targeted by sanctions suggests that the sanctions do have meaningful consequences.

This evidence suggests that terrorists can be affected by sanctions. Groups are likely to have less funds to work with, actors who might interact with them in the future are discouraged, and the groups are forced to resort to riskier financing tactics. This suggests overall weaker terrorist groups, organizations less able to carry out attacks. However, sanctions do not seem to affect all terrorist groups equally. 


\section{The conditioning effect of U.S. allies}

While it seems possible that designation and the resulting sanctions could reduce groups' ability to carry out attacks, it is also likely that this impact depends on the context in which the group operates. Groups operating in U.S.-aligned countries are more likely to be affected by U.S. sanctions than groups operating in other countries. Allies are important for terrorist group sanctions for a number of reasons. For U.S. sanctions to be effective at confronting foreign terrorist groups, partners are needed to share intelligence on the groups, share information about financial flows, and assist with local arrests based on information from the United States. This cooperation is especially beneficial when it involves the country in which an FTO is based. The argument is not necessarily about allies in a formal sense, but any state that cooperates on counterterrorism. It has been shown that cooperation among terrorist groups can help those groups attacking states (Asal and Rethemeyer, 2008; Moghadam, 2017), so it seems likely that the obverse side is also true: international cooperation should help states confront terrorist groups.

There are important reasons states might not cooperate on counterterrorism (Enders and Sandler, 2012: 170-200). For example, there are collective action problems, ideological differences, and the fact that groups threaten different states to different degrees. States do not always agree on which groups are "terrorist groups." Cooperating with a sometimesunpopular country like the United States can provoke local grievances (e.g., Rosendorff and Sandler 2004). However, these issues are often overcome, through shared ideology, common threats, financial compensation, and other mechanisms, and states do indeed cooperate on counterterrorism. ${ }^{14}$ This can lead to substantial consequences. For example, Spanish counterterrorism benefitted from US cooperation in the fight against ETA. In addition to putting pressure on the group via economic sanctions, the United States offered 
to gather information on the communications of ETA members using the capabilities of the National Security Agency (Tremlett, 2001). U.S. cooperation is argued to have contributed substantially to the increase in arrests of ETA members in Spain and abroad in the early 2000s (Ramos, 2005: 127-129). ${ }^{15}$

Two Southeast Asian countries, the Philippines and Indonesia, provide interesting points of comparison regarding how international cooperation can affect FTOs. The Philippines, a long-term military ally of the United States, has been especially effective at disrupting terrorist financing and plots. ${ }^{16}$ The Philippines is home to a variety of terrorist organizations, including the FTO Abu Sayyaf. This country is more likely to discourage the funding of FTOs, more likely to share information about funding with the United States, and as a result should be overall especially effective in weakening the FTOs in its territory.

Neighboring Indonesia appears to have had a different level of commitment to counterterrorism, at least until recent years. Much of this difference is due to skepticism in the Indonesian public for U.S.-led counterterrorism. The consequence has been years of lukewarm counterterrorism. For example, the US government designated Indonesian group Jemaah Islamiyah as an FTO in 2002, but the Indonesian government resisted banning the group until 2008 (Forbes, 2008). Regarding prosecution of terror financing, Indonesia was for years labeled as non-cooperative or deficient by the Financial Action Task Force (Financial Action Task Force, 2014). This singling out is informally known as the "blacklist," and Indonesia joined countries such as Algeria and Myanmar in the distinction, until its status was upgraded in 2015 (Financial Action Task Force, 2015). Indonesia increasingly cooperates with the United States on counterterrorism (e.g., U.S. Department of State, 2010), but apparently not to the same degree as other countries such as the Philippines, especially in the years immediately after 9/11. 
Overall, some evidence suggests that FTO designation could reduce terrorist attacks, which is what proponents of the FTO list would assert.

H1: Groups on the FTO list carry out fewer terrorist attacks over time, relative to groups not on the list.

However, the conditional argument presented above implies that FTO status should only reduce the terrorism of organizations in certain kinds of countries. This idea, the main argument of this article, can be summarized as follows:

H2: Groups on the FTO list and operating in states that cooperate with the United States on security issues carry out fewer terrorist attacks over time, relative to groups not on the list and not operating in U.S.-aligned countries.

\section{Empirical analysis}

\section{Data and variables}

Analyses use data on hundreds of terrorist groups around the world, from 19702006. ${ }^{17}$ These data are a combination of the Jones and Libicki (2008) terrorist group data and the Global Terrorism Database (GTD) attack data. The Jones and Libicki data set is widely used in terrorism studies (e.g., Carter, 2012). It includes basically every group in the world who was reported to have carried out a terrorist attack, and for which additional information can be found. This rather broad understanding of "terrorist group," any subnational group that uses terrorism (even if other analysts might think of some of the groups as guerrilla or insurgent organizations), is relevant for this study because it is

consistent with many governments' understanding of terrorist groups. ${ }^{18}$ Some of Jones and Libicki's groups only have attacks for one year, which does not permit us to look at 
changes over time, or to lag variables. As a result, the primary models reported here have 390 terrorist groups, but others have more or less, depending on the sample used. The unit of analysis is terrorist group-year. Primary models have 4,469 group-year observations.

The dependent variable is Change in attacks, based on a count of GTD attacks associated with each group. The GTD is the most commonly used and comprehensive database of attacks available globally and for so many years, and most attacks are associated with a group via GTD's gname variable. Since the dependent variable is a change or delta variable, it measures the difference between the number of attacks associated with the group during the year of analysis, and the number of the group's attacks in the previous year. This measure varies considerably, but is normally distributed and ranges between -253 and 311 in the primary sample. Terrorist attacks are an important outcome of interest, widely studied as a key terrorist organizational output (e.g., Hoffman, 2006: 248-249; Li, 2005; Piazza, 2008). ${ }^{19}$ Changes in attacks are not a key factor behind designation, or remaining on the list. ${ }^{20}$

Beyond this measure, one robustness check includes the change of attacks in the group's country that year. This is to deal with the issue that many attacks are not claimed by groups (Kearns, Conlon, and Young 2014). It also allows us to explore the possibility that counterterrorism activity against one group might affect other groups - as recent literature suggests (Tominaga 2018). Another robustness check, in the appendix, uses changes in groups' fatalities instead of their attacks as the dependent variable.

[Table 1 about here.] 
The key independent variable $F T O_{t-1}$ is coded " 1 " in the years that the group is on the FTO list. Data come from the U.S. State Department, and the groups are shown in Table 1. A total of 41 groups were on the list at some point between 1997 and 2006 and appear in the sample, although the number changed regularly. The fact that many of the groups were listed en masse in 1997 adds some exogeneity to the timing of designation. In general, it does not appear that groups were added when they were especially strong or weak. A oneyear lag is used to take into consideration that some time might be necessary for sanctions to have their effects.

An alternate measure of FTO status is also tested, a count variable of years on the FTO list instead of the dichotomous measure. This variable is used because if the argument is correct, it seems likely that additional years of FTO status will be associated with reduced terrorism - but only or primarily for groups in U.S.-aligned countries. This variable ranges from 0 to 10 . See Table 1 for more information.

Another key independent variable measures alignment with the United States on security issues. There is no ideal measure of a country's propensity to cooperate with the United States on counterterrorism issues in particular. The first and primary measure is U.S. ally, coded 1 for groups operating in a country that is in a formal military alliance with the United States. ${ }^{21}$ Scholars have long used alliance membership to proxy similar foreign policy or security interests (e.g., Bueno de Mesquita 1975). About half the groups in the sample are coded as being in countries that are aligned with the United States by this measure. Alliance data come from the Alliance Treaty Obligations and Provisions (ATOP) project (Leeds et al., 2002). ${ }^{22}$ ATOP only codes alliances through 2003, but I extended the data through 2006 with information from the director of ATOP. This is a widely-cited 
alliance database, coding hundreds of military alliances around the world based on clear and consistent criteria.

About half the groups in the sample are coded as being in countries that are aligned with the United States by this measure. Interestingly, U.S. ally and $F T O_{t-1}$ are virtually uncorrelated. Alliances are an imperfect measure of security cooperation because alliances do not always match up perfectly with actual counterterrorism partners (Byman 2006). Joint alliance membership nonetheless indicates security cooperation, and this measure is consistently measured across time and space, which offers advantages over other measures.

Two alternate measures of security cooperation are used. First, Model 5 uses U.S. alliance portfolio similarity, Signorino and Ritter's (1999) weighted S-score, made available by Häge (2011). This measure considers the overlap between two states' portfolio of military alliances. ${ }^{23}$ It has been used in other studies as an indicator of potential counterterrorism cooperation (Bapat, 2007). Since closeness to the United States is of interest, the measure is the closeness to the U.S. alliance portfolio for the state in which each terrorist group primarily operates. The variable is only available through 2000 , but it does not change much over time, so I extend the 2000 values through $2006 .{ }^{24}$ A second alternative is a dichotomous variable indicating the presence of an FBI office in the country, which Efrat (2015) argues is an important indicator of counterterrorism cooperation. By 2006, 56 countries had such an office. This variable only has information from 1993 onward, so the sample is smaller than others. However, the FBI has been crucial in U.S. international counterterrorism efforts, so this is an important alternate measure. Regarding control variables, the group fixed effects in most models prohibit the use of variables that do not vary over time. Models include both terrorist organization control variables, and state-level controls. Regarding organizational controls, models include 


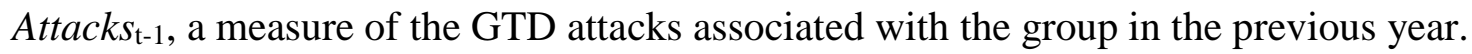
This is to provide a baseline of the group's activity. Group age is the number of years the group has existed, usually according to Jones and Libicki. Age squared is also included because it is likely that there is a non-linear relationship between age and changes in attacks (Asal and Rethemeyer 2008).

Models also include a measure of "decapitations" the group has suffered, when a high-ranking leader was killed or captured. Decapitation can reduce the violence of terrorist organizations (Price, 2012; Johnston, 2012). It is also included to take into consideration to what extent the group has been targeted by the state, as there is substantial variation among groups in this regard. The measure comes from Price (2012). It is lagged one year because there might be a delay between decapitation and potential effects on attack output.

Several other group-level variables are only included in the non-fixed-effects models because they do not vary over time and therefore are too correlated with the group fixed effects. UCDP rebel group is coded 1 for groups that are listed in the Uppsala Conflict Data Program Actor Dataset (UCDP, 2015). This variable is included because the notion of "terrorist group" is broad, and some groups, such as those that have been in civil conflict, might be thought of as a different subcategory of actor. Group size is an ordinal measure approximating the peak membership of the group, where 0 means fewer than 99 members, 1 is 100 to 999 members, 2 indicates 1,000-9,999 members, and 3 indicates groups with 10,000 or more. This is a rough approximation, but the best that is currently available for the hundreds of terrorist groups around the world. The source is the Jones and Libicki data. Larger groups should carry out more attacks (Asal and Rethemeyer, 2008).

Religious is a variable coded "1" for groups primarily motivated by a religion, as opposed to leftist or rightist ideology, or other goals. Religious groups are often more 
violent that other types of terrorist organizations (Asal and Rethemeyer, 2008). The source is the Jones and Libicki data. Holds territory is coded " 1 " for groups exercising control over a substantial piece of territory for a sustained period. Sources consulted include Lexis Nexis searches and the Asal and Rethemeyer (2008) data for some years. State sponsored is coded "1" for groups receiving material support from a state, whether weapons, funds, or otherwise. This variable is coded using the same sources as those for the territory variable, and the RAND Terrorist Organization Profiles data, which has information on group funding. Holds territory and State sponsored are time invariant because there is not enough reliable information on temporal changes in these phenomena for clandestine groups.

Control variables are also included to take into consideration attributes of the country in which each group primarily operates. For most groups the state of primary operation was easy to classify, even though many groups carry out some transnational attacks. Some groups are more complicated, such as al Qaeda. It was coded as primarily operating in Afghanistan through 2001, and then in Pakistan in subsequent years. If al Qaeda is excluded, results hold.

Country regime type is the Varieties of Democracy (V-Dem) liberal democracy measure (Coppedge et al. 2016), where a higher score indicates a more democratic country. Some research suggests democratic countries experience more terrorism than other kinds of countries (Chenoweth 2010). It comes via the Quality of Government data (Teorell et al. 2018). GDPPC is a measure of the gross domestic product per capita of the country, in thousands of constant dollars. This comes from the Penn World Tables, via Quality of Government. GDPPC could have a negative relationship with Change in attacks, as higher income per capita could indicate state capacity, and therefore counterterrorism capacity (Fearon and Laitin 2003). Population ( $\log$ ) is a natural logarithm of the country's 
population that year. Larger countries tend to have more terrorism (Piazza, 2011), and as a result, perhaps groups in these countries should use more terrorism with time. This variable also comes from the Penn World Tables, via the Quality of Government project.

\section{Estimator}

The models are ordinary least-squares regressions due to the normal distribution of the dependent variable. They include group fixed effects to take into consideration that groups are being observed repeatedly, and because there are group-level factors that we might not be able to measure. Hausman tests indicate that fixed effects are preferable to random effects. One disadvantage of fixed effects models is that they cannot include time invariant-variables. A model without fixed effects is shown in Table 3, and this model includes additional independent variables that do not change over time. A Wooldridge test suggests the presence of autocorrelation, so models include AR(1) disturbances (Baltagi and $\mathrm{Wu} 1999)$. Year fixed effects cannot be included with the AR(1) disturbances, but results are similar if year fixed effects are used instead. Alternate specifications are presented below or in the online Appendix.

\section{Results}

The primary results are shown in Table 2 . The first model includes only control variables as a baseline. Results for these variables are discussed below. Model 2 introduces the measure $F T O_{t-1}$, and it is statistically significant and negatively signed, suggesting a group that was an FTO in the previous year is expected to see a decrease in attacks by the

following year. The coefficient for the FTO variable suggest a group should carry out about 7 fewer attacks than it did in the previous year if it is an FTO. This suggests support for 
Hypothesis 1, but this is an unconditional result. Other models suggest a more complex relationship between FTO status and group attacks. Model 3 includes U.S. ally, the coefficient on the variable in Model 2 is statistically insignificant, suggesting that simply operating in a U.S.-allied state is not associated with a change in a group's number of attacks each year.

[Table 2 about here.]

Model 4, the main model, includes the interaction term of $F T O_{t-1}$ and U.S. ally. The coefficient on the interaction term is statistically significant and negatively signed, suggesting that if a group was designated an FTO, and operates primarily in U.S.-allied state, it is expected to carry out fewer attacks in the year under observation than in the previous year. Figure 1 graphs the estimated marginal effect of FTO status on a group's yearly change in attacks - conditional upon U.S. alliance status. FTOs that are not in U.S.allied states do not have a statistically significant change in attacks when compared to nonFTOs. However, FTOs in U.S.-allied states are estimated to carry out around 16 fewer attacks from year to year, compared with non-FTOs. These results suggest support for Hypothesis 2.

[Figure 1 about here.]

In Model 4, $F T O_{t-1}$ is statistically insignificant, but this should be interpreted as the effect of being on the FTO list in the previous year, conditional upon not being in an alliance with the United States. This component term result suggests that FTO status is not 
associated with a change in terrorist attacks for those groups that do not primarily operate in U.S.-allied states. This is consistent with the results in Figure 1, and substantially qualifies support for Hypothesis 1.

Model 5 incorporates the alternate measure of security cooperation with the United States, U.S. alliance portfolio similarity. This is continuous measure of the same concept that U.S. ally is intended to proxy, security cooperation with the United States. The results are similar to those of U.S. ally. Since U.S. alliance portfolio similarity is continuous, it is helpful to graph the effects FTO status at different levels of alliance similarity.

[Figure 2 about here.]

Figure 2 graphs the expected effect of $F T O_{t-1}$ at different levels of the continuous measure U.S. alliance portfolio similarity. The diagonal line, representing the association between FTO status and changes in attacks, has a steep slope. This suggests that the effect of FTO designation on terrorist attacks depends markedly on to what extent the state in which they primarily operate cooperates with the United States on security issues. For FTOs in countries with quite distinct alliance portfolios from that of the United States, such as Lebanon or Libya, FTO status is associated with no change in attacks. (The far-left side of Figure 1 suggests an increase in attacks, but there are no FTO observations at this extreme end.) For FTOs that operate in states with alliance portfolios close to the United States, such as Colombia or Turkey, these groups are expected to see decreases of approximately 16 (Colombia) or 22 (Turkey) fewer attacks since the previous year, other factors held constant. To refer to two examples discussed earlier in the article, Indonesia in 2000 had a weighted S-score of about .07, while the Philippines had a weighted S-score of 
about .40. Figure 1 suggests that FTO status for groups in Indonesia is not associated with a change in their attacks. The line is statistically insignificant at that point. However, FTO status for groups in the more U.S.-aligned Philippines is associated with a reduction of about 12 attacks per year. Models 4 and 5 provide evidence in favor of Hypothesis 2.

Regarding control variables in Table 2, Attacks $_{t-1}$ is statistically significant and negative in all models, suggesting a higher level of attacks in the previous year is associated with a decrease between that year and the following. This suggests a return-to-the the mean phenomenon. It is important to control for such trends. Group age is statistically insignificant, but its squared term is marginally significant and negative in all models of Table 2. If the combined effect is calculated, increasing age is associated with decreased attacks, but only for unusually old groups (>30 years). A non-linear relationship between group age and attacks or lethality is consistent with other studies (Asal and Rethemeyer 2008). The leadership removal variable is negatively signed as expected, but statistical significance is not robust. Additional group-level controls are shown in Table 3.

Regarding state-level variables, country regime type is statistically significant and positively signed in all models. Groups in more democratic countries carry out more attacks over time. This is consistent with some research on democracy and terrorism (e.g., Chenoweth 2010). Country population and per capita GDP are statically insignificant in most models. (If a GDP squared term is included, there is no evidence of a non-linear relationship.) These variables are statistically significant in Model 8, with the country dependent variable, suggesting country dynamics are important for explaining a country’s terrorism, consistent with the literature. For the group dependent variable, it makes sense that group factors seem to matter more.

[Table 2 about here.] 


\section{Additional specifications and robustness checks}

Table 3 shows alternate specifications of Model 4, the primary interaction term model, to gauge the robustness of relationships in that model. (If Model 5 is used, with U.S. alliance portfolio similarity, results are similar.) Results for the interaction term relationship are consistent across all models in terms of the significance and direction of the relationship. Being on the FTO list and operating in a U.S.-aligned country is robustly associated with decreased terrorist attacks.

Model 6 excludes group fixed effects to account for group-level heterogeneity in different ways and includes time-invariant variables. In both models, standard errors are clustered by terrorist group. Some time-invariant independent variables return interesting results. UCDP rebel group is statistically significant and positive, suggesting groups that have been in civil conflict carry out more attacks over time. Group size is also statistically significant and positive, consistent with expectations. ${ }^{25}$ Religious group is statistically insignificant. The relationship between religion and terrorism is debated, and probably conditional on other factors (Piazza, 2009), so the non-result is not necessarily surprising. If an "Islamist" measure is used instead of religious generally, it is similarly insignificant. Neither holding territory nor state sponsorship is associated with changes in attacks.

Model 7 uses a considerably smaller sample, only 1997-2006. These years are used because the FTO list started in 1997. The larger sample is generally preferable, because many groups existed for years earlier than 1997, and truncating the sample drops a great deal of information about these groups. However, the post-1996 sample is interesting to evaluate as well. Most of the control variables in this model are statistically insignificant. The sample in Model 7 is substantially smaller than those examined in other models, so this could explain differences in results. 
Model 8 uses an alternate dependent variable, the change in attacks in the entire country that the group primarily operates in, from one year to the next. This is helpful because many attacks are not attributed to particular groups, so the primary dependent variable could be undercounting group attacks. The country measure could also capture spillover effects of FTO status on other groups (Tominaga 2018), since militant organizations often train and attack together. Consistent with this, the interaction term is negatively signed and statistically significant. ${ }^{26}$

Model 9 includes an alternate measure of FTO status. Instead of the dichotomous measure, this model uses a count indicating the number of years the group had been on the FTO list. This operationalization of FTO status is introduces important temporal variation into the measure. The variable is also interesting is because we might expect cumulative effects. Indeed, results are overall robust. The coefficient on the interaction term is about negative three. With each additional year of FTO status, for groups in U.S.-allied countries, a group is expected to carry out three fewer attacks. However, the component term $F T O_{t-1}$ is positively signed and marginally statistically significant. This suggests that for groups that operate in states that are not U.S. allies (U.S. ally=0), another year on the FTO list is associated with a slight increase in terrorist attacks. This could be the result of some backlash effect, perhaps increased visibility due to FTO status, that groups are able to capitalize upon if they are in a country that is not cooperating with the United States on the implementation of its sanctions. Given that the result is only marginally significant and insignificant in other models, one should probably not infer too much from the positive coefficient.

Finally, Model 10 uses an alternate measure of propensity to cooperate with the United States on counterterrorism issues: Efrat's (2015) indicator of the presence of an FBI 
office in the country. The main result, the interaction term, is robust with this different operationalization of U.S. security cooperation.

Beyond the robustness checks shown in the table, many other modifications to the sample and variables return consistent results. In the Appendix, one model is a traditional OLS fixed-effects model, since the AR(1) models have fewer observations because the first observation (year) for each group is dropped. With this larger sample, results are robust. Another Appendix model uses an alternate dependent variable, changes in terrorist attack fatalities instead of simply attacks. Other models include additional independent variables, U.S. military aid to the group's country and physical integrity rights in the group's country. These variables are not included in the main models as they cause many observations to drop due to limited coverage. An additional test in the Appendix involves a measure of US allies that excludes NATO countries, to ensure that those states are not driving results. Findings are consistent in all these analyses. In sum, the results in Table 2 are robust to many changes in model specification.

Regarding goodness of fit, models in Table 1 report Akaike Information Criterion and Bayesian Information Criterion values, where a lower score indicates a better model fit. These values suggest the models with the interaction term (Models 4 and 5) fit better than the simpler models in the table, in terms of both AIC and BIC. It is noteworthy that both estimators, especially the BIC, penalize for additional terms in the model.

In the Appendix, predicted values are plotted against observed values and discussed. Some observations that were not predicted well by the model were those during years of massive increases in terrorism, such as Spain's ETA in 2000, the FARC in 2002, or Sri Lanka's Tamil Tigers in 2005. It can be difficult to account for such outliers, but future research could incorporate more fine-grained measures of state negotiation processes or 
crackdowns, as these often precede spikes in terrorism. Some observations that the model did especially well with, relative to a model without the interaction term, were of FTOs in countries not aligned with the United States. The model without the interaction term was often worse in these situations, over-predicting decreases in violence. Overall, the model offers an improvement over models that do not consider the interaction of FTO status and alignment with the United States on counterterrorism.

\section{Conclusion}

States increasingly impose sanctions against terrorist groups, but there has been little systematic analysis of whether these policies achieve intended effects. The results presented here suggest that sanctions of the U.S. Foreign Terrorist Organization list are associated with reduced terrorist attacks (by the group and in the country more generally), and fewer terrorism fatalities, over time - but only for groups located in countries aligned with the United States on security issues. The findings point to the importance of terrorism funding and organizational dynamics, and to international counterterrorism cooperation. Fighting terrorism is far more effective when countries cooperate.

Some shortcomings of the research should be acknowledged. First, a tradeoff with global analyses is that they cannot go into fine-grained detail about particular cases. Complementary work could examine specific militant groups in depth to see if the dynamics outlined here are observed as theorized. Related to this, qualitative work or new data-collection efforts could look at more detailed militant group attributes, such as group funding sources and internal group structure. Second, the analysis examined years through 2006 due to data availability. This means that the quantitative tests studied 10 years of the existence of the FTO list, which is a substantial amount of time, and includes the important 
early years of the "War on Terror." However, significant events have happened in terrorism since 2006, such as the rise of ISIS. As a result, this analysis is an initial step, a study of the first decade of the FTO list. A next step would be to analyze more recent dynamics.

There are other avenues for future research to build on this study. Given the importance of international cooperation to counterterrorism, what other ways do international relationships contribute to strategies against terrorist organizations? Despite the benefits of international counterterrorism cooperation, there are impediments to cooperation, such as mistrust, in the case of intelligence sharing (Walsh, 2006). Under what conditions are states especially likely to overcome the obstacles to international counterterrorism cooperation? More broadly, how else do international relations affect terrorism? Some research has looked at international cooperation (Byman, 2006; Conrad and Walsh, 2014; Plumper and Neumayer, 2010), foreign aid (Lee, 2016), and international organizations (Pascoe 2016), but more work can be done to integrate explicitly international phenomena into the study of terrorism.

Finally, how do analyses of counterterrorism policies speak to each other? Research in this category includes studies of airport metal detectors (Enders and Sandler, 1993), targeting leaders of militant groups (Johnston, 2012; Jordan, 2014), and deradicalization programs (Horgan and Braddock, 2010). What tactics have been the most effective? Some studies explicitly compare policies in a systematic way (Enders and Sandler, 1993), but this kind of research has been rare. The present manuscript looked at leadership removal in addition to FTO status, finding the latter to be more robustly associated with changes in terrorism. Future research should consider incorporating FTO status into analyses of counterterrorism policies. 
Table 1. Groups on the Foreign Terrorist Organization List, 1997-2006

\begin{tabular}{|c|c|c|c|}
\hline Group & Country & Listed & Removed \\
\hline Abu Nidal Organization & Lebanon & 1997 & 2017 \\
\hline Abu Sayyaf Group & Philippines & 1997 & -- \\
\hline Armed Islamic Group & Algeria & 1997 & 2010 \\
\hline Aum Shinrikyo & Japan & 1997 & -- \\
\hline Basque Fatherland and Liberty & Spain & 1997 & -- \\
\hline DFLP-Hawatmeh Faction & Israel & 1997 & 1999 \\
\hline Gama'a al-Islamiyya (Islamic Group - IG) & Egypt & 1997 & -- \\
\hline HAMAS & Israel & 1997 & -- \\
\hline Harakat ul-Mujahidin (HUM) & Pakistan & 1997 & -- \\
\hline Hizballah & Lebanon & 1997 & -- \\
\hline Japanese Red Army & Japan & 1997 & 2001 \\
\hline Kahane Chai (Kach) & Israel & 1997 & -- \\
\hline Khmer Rouge & Cambodia & 1997 & 1999 \\
\hline Kurdistan Workers Party (PKK, aka Kongra-Gel) & Turkey & 1997 & -- \\
\hline Liberation Tigers of Tamil Elam (LTTE) & Sri Lanka & 1997 & -- \\
\hline Manuel Rodriguez Patriotic Front Dissidents & Chile & 1997 & 1999 \\
\hline Mujahedin-e-Khalq Organization & Iran, France, Iraq & 1997 & 2012 \\
\hline National Liberation Army (ELN) & Colombia & 1997 & -- \\
\hline Palestine Liberation Front (PLF) & Israel & 1997 & -- \\
\hline Palestine Islamic Jihad (PIJ) & Israel & 1997 & -- \\
\hline Popular Front for the Liberation of Palestine & Israel & 1997 & -- \\
\hline PFLP-General Command (PFLP-GC) & Lebanon & 1997 & -- \\
\hline Revolutionary Armed Forces of Colombia (FARC) & Colombia & 1997 & -- \\
\hline Revolutionary Nuclei & Greece & 1997 & 2009 \\
\hline Revolutionary Organization 17 November & Greece & 1997 & 2015 \\
\hline Revolutionary People's Liberation Party/Front & Turkey & 1997 & -- \\
\hline Shining Path (SL) & Peru & 1997 & -- \\
\hline Tupac Amaru Revolution Movement & Peru & 1997 & 2001 \\
\hline al-Qa'ida (AQ) & Afghanistan, Pakistan & 1999 & -- \\
\hline Islamic Movement of Uzbekistan (IMU) & Uzbekistan & 2000 & -- \\
\hline Real Irish Republican Army & United Kingdom & 2001 & -- \\
\hline Jaish-e-Mohammed & Pakistan & 2001 & -- \\
\hline Lashkar-e Tayyiba & Pakistan & 2001 & -- \\
\hline United Self Defense Force of Colombia & Colombia & 2001 & 2014 \\
\hline Al-Aqsa Martyrs Brigade & Israel & 2002 & -- \\
\hline Asbat al-Ansar & Lebanon & 2002 & -- \\
\hline al-Qaida in the Islamic Maghreb & Algeria & 2002 & -- \\
\hline Communist Party Philippines/New People's Army & Philippines & 2002 & -- \\
\hline Jemaah Islamiya & Indonesia & 2002 & -- \\
\hline Lashkar i Jhangvi & Pakistan & 2003 & -- \\
\hline Ansar al-Islam & Iraq & 2004 & -- \\
\hline Continuity Irish Republican Army & United Kingdom & 2004 & -- \\
\hline ISIL (formerly al-Qa'ida in Iraq) & Iraq & 2004 & -- \\
\hline Libyan Islamic Fighting Group & Libya & 2004 & 2015 \\
\hline Islamic Jihad Union & Uzbekistan & 2005 & -- \\
\hline Moroccan Islamic Combat Group & Morocco & 2005 & 2013 \\
\hline
\end{tabular}

Source: U.S. State Department. Names are spelled as they are on State's website, but some are abbreviated. Country refers to primary location. Some groups are shown with multiple countries because they changed their primary location over time. 
Table 2. Fixed effects regressions of changes in terrorist groups' attacks, 1970-2006.

\begin{tabular}{|c|c|c|c|c|c|}
\hline & $\begin{array}{l}\text { Model } 1 \\
\text { controls } \\
\text { only }\end{array}$ & $\begin{array}{c}\text { Model } 2 \\
\text { FTO }\end{array}$ & $\begin{array}{l}\text { Model } 3 \\
\text { US ally }\end{array}$ & $\begin{array}{c}\text { Model } 4 \\
\text { Main model }\end{array}$ & $\begin{array}{c}\text { Model 5 } \\
\text { Alternate } \\
\text { US ally } \\
\text { measure: } \\
\text { U.S. alliance } \\
\text { portfolio } \\
\text { similarity } \\
\end{array}$ \\
\hline $\mathrm{FTO}_{\mathrm{t}-1}$ & & $\begin{array}{c}-6.728 * * * \\
(1.513)\end{array}$ & & $\begin{array}{c}1.706 \\
(2.066)\end{array}$ & $\begin{array}{c}1.301 \\
(1.958)\end{array}$ \\
\hline US ally & & & $\begin{array}{l}-1.198 \\
(1.824)\end{array}$ & $\begin{array}{c}.104 \\
(1.861)\end{array}$ & $\begin{array}{l}-3.209 \\
(5.760)\end{array}$ \\
\hline $\begin{array}{l}\mathrm{FTO}_{\mathrm{t}-1} \times \mathrm{US} \\
\text { ally }\end{array}$ & & & & $\begin{array}{c}-17.320 * * * \\
(2.828)\end{array}$ & $\begin{array}{c}-32.207 * * * \\
(4.884)\end{array}$ \\
\hline Attacks t-1 & $\begin{array}{c}-.343 * * * \\
(.013)\end{array}$ & $\begin{array}{c}-.355 * * * \\
(.013)\end{array}$ & $\begin{array}{c}-.343 * * * \\
(.013)\end{array}$ & $\begin{array}{c}-.366 * * * \\
(.013)\end{array}$ & $\begin{array}{c}-.370 * * * \\
(.013)\end{array}$ \\
\hline Group age & $\begin{array}{l}-.036 \\
(.082)\end{array}$ & $\begin{array}{c}.055 \\
(.083)\end{array}$ & $\begin{array}{l}-.043 \\
(.082)\end{array}$ & $\begin{array}{c}.024 \\
(.083)\end{array}$ & $\begin{array}{c}.052 \\
(.085)\end{array}$ \\
\hline Age squared & $\begin{array}{l}-.002 * \\
(.001)\end{array}$ & $\begin{array}{c}-.002 * * \\
(.001)\end{array}$ & $\begin{array}{l}-.002 * \\
(.001)\end{array}$ & $\begin{array}{l}-.002 * \\
(.001)\end{array}$ & $\begin{array}{l}-.002 * \\
(.001)\end{array}$ \\
\hline Decapitations $\mathrm{t}-1$ & $\begin{array}{l}-1.984 * \\
(1.030)\end{array}$ & $\begin{array}{l}-1.643 \\
(1.030)\end{array}$ & $\begin{array}{l}-1.988^{*} \\
(1.030)\end{array}$ & $\begin{array}{l}-1.810^{*} \\
(1.026)\end{array}$ & $\begin{array}{l}-1.746^{*} \\
(1.025)\end{array}$ \\
\hline $\begin{array}{l}\text { Country } \\
\text { regime type }\end{array}$ & $\begin{array}{c}10.11 * * * \\
(3.496)\end{array}$ & $\begin{array}{c}9.518 * * * \\
(3.512)\end{array}$ & $\begin{array}{c}10.25 * * * \\
(3.502)\end{array}$ & $\begin{array}{c}11.106 * * * \\
(3.516)\end{array}$ & $\begin{array}{c}12.11 * * * \\
(3.576)\end{array}$ \\
\hline $\begin{array}{l}\text { Country } \\
\text { population }\end{array}$ & $\begin{array}{c}.262 \\
(2.712)\end{array}$ & $\begin{array}{c}-.408 \\
(2.583)\end{array}$ & $\begin{array}{c}.518 \\
(2.740)\end{array}$ & $\begin{array}{c}.510 \\
(2.542)\end{array}$ & $\begin{array}{l}-1.693 \\
(2.526)\end{array}$ \\
\hline GDPPC & $\begin{array}{l}-.115 \\
(.147)\end{array}$ & $\begin{array}{l}-.145 \\
(.147)\end{array}$ & $\begin{array}{l}-.112 \\
(.147)\end{array}$ & $\begin{array}{l}-.127 \\
(.147)\end{array}$ & $\begin{array}{l}-.073 \\
(.152)\end{array}$ \\
\hline Constant & $\begin{array}{l}-1.922 \\
(27.58)\end{array}$ & $\begin{array}{c}4.882 \\
(26.08)\end{array}$ & $\begin{array}{l}-4.058 \\
(27.76)\end{array}$ & $\begin{array}{l}-5.262 \\
(25.51)\end{array}$ & $\begin{array}{c}17.96 \\
(25.13)\end{array}$ \\
\hline $\begin{array}{l}\text { Group fixed } \\
\text { effects? }\end{array}$ & Yes & Yes & Yes & Yes & Yes \\
\hline $\begin{array}{l}\mathrm{AR}(1) \\
\text { disturbances? }\end{array}$ & Yes & Yes & Yes & Yes & Yes \\
\hline $\begin{array}{l}\text { Observations } \\
\text { (groups) }\end{array}$ & $\begin{array}{l}4,469 \\
(390)\end{array}$ & $\begin{array}{l}4,469 \\
(390)\end{array}$ & $\begin{array}{l}4,469 \\
(390)\end{array}$ & $\begin{array}{l}4,469 \\
(390)\end{array}$ & $\begin{array}{l}4,376 \\
(347)\end{array}$ \\
\hline AIC & 37451.02 & 37438.01 & 37452.57 & 37402.39 & 37396.85 \\
\hline $\mathrm{BIC}$ & 37502.26 & 37495.66 & 37510.22 & 37472.84 & 37467.31 \\
\hline
\end{tabular}


Table 3. Additional specifications based on Model 4

\begin{tabular}{|c|c|c|c|c|c|}
\hline & $\begin{array}{c}\text { Model } 6 \\
\text { No group } \\
\text { fixed effects; } \\
\text { time- } \\
\text { invariant } \\
\text { controls }\end{array}$ & $\begin{array}{c}\text { Model 7 } \\
\text { Only 1997- } \\
2006\end{array}$ & $\begin{array}{l}\text { Model } 8 \\
\text { Alternate } \\
\text { DV: } \\
\text { Attacks in } \\
\text { group's } \\
\text { country }\end{array}$ & $\begin{array}{l}\text { Model } 9 \\
\text { Alternate } \\
\text { FTO } \\
\text { measure: } \\
\text { Years on } \\
\text { FTO list }\end{array}$ & $\begin{array}{c}\text { Model } 10 \\
\text { Alternate } \\
\text { US ally } \\
\text { measure: } \\
\text { FBI office } \\
\text { in country }\end{array}$ \\
\hline $\mathrm{FTO}_{\mathrm{t}-1}$ & $\begin{array}{c}1.418 \\
(1.161)\end{array}$ & $\begin{array}{l}-.610 \\
(2.113)\end{array}$ & $\begin{array}{c}-16.14 \\
(12.515)\end{array}$ & $\begin{array}{l}.709 * \\
(.394)\end{array}$ & $\begin{array}{c}.297 \\
(1.944)\end{array}$ \\
\hline US ally & $\begin{array}{c}1.726 * * * \\
(.525)\end{array}$ & $\begin{array}{l}10.121 \\
(8.622)\end{array}$ & $\begin{array}{c}-23.30 * * \\
(11.50)\end{array}$ & $\begin{array}{c}.133 \\
(1.852)\end{array}$ & $\begin{array}{c}.779 \\
(1.095)\end{array}$ \\
\hline $\begin{array}{l}\mathrm{FTO}_{\mathrm{t}-1} \times \mathrm{US} \\
\text { ally }\end{array}$ & $\begin{array}{c}-4.782 * * * \\
(1.604)\end{array}$ & $\begin{array}{c}-11.441 * * * \\
(3.218)\end{array}$ & $\begin{array}{c}-60.074 * * * \\
(17.31)\end{array}$ & $\begin{array}{c}-3.451 * * * \\
(0.555)\end{array}$ & $\begin{array}{c}-10.524 * * * \\
(2.281)\end{array}$ \\
\hline Attacks t-1 & $\begin{array}{c}-.134 * * * \\
(.029)\end{array}$ & $\begin{array}{c}-.921 * * * \\
(.028)\end{array}$ & $\begin{array}{c}-.998 * * * \\
(.015)\end{array}$ & $\begin{array}{c}-.366 * * * \\
(.013)\end{array}$ & $\begin{array}{c}-.911^{* * * *} \\
(.024)\end{array}$ \\
\hline Group age & $\begin{array}{l}-.069 \\
(.049)\end{array}$ & $\begin{array}{l}.492^{*} \\
(.279)\end{array}$ & $\begin{array}{c}.705 \\
(.654)\end{array}$ & $\begin{array}{l}-.012 \\
(.082)\end{array}$ & $\begin{array}{c}.658 * * * \\
(.243)\end{array}$ \\
\hline Age squared & $\begin{array}{l}.001 \\
(.000)\end{array}$ & $\begin{array}{l}-.003 \\
(.005)\end{array}$ & $\begin{array}{l}-.005 \\
(.010)\end{array}$ & $\begin{array}{l}-.002 * \\
(.001)\end{array}$ & $\begin{array}{c}-.013 * * * \\
(.004)\end{array}$ \\
\hline Decapitations $\mathrm{t}-1$ & $\begin{array}{l}-1.113 \\
(.776)\end{array}$ & $\begin{array}{l}-.842 \\
(.615)\end{array}$ & $\begin{array}{l}-4.419 \\
(3.219)\end{array}$ & $\begin{array}{l}-2.094 * * \\
(1.027)\end{array}$ & $\begin{array}{l}-.521 \\
(.649)\end{array}$ \\
\hline $\begin{array}{l}\text { Country } \\
\text { regime type }\end{array}$ & $\begin{array}{c}1.595 \\
(1.854)\end{array}$ & $\begin{array}{c}4.628 \\
(7.318)\end{array}$ & $\begin{array}{c}123.9 * * * \\
(23.65)\end{array}$ & $\begin{array}{c}11.59 * * * \\
(3.518)\end{array}$ & $\begin{array}{c}10.47 \\
(6.446)\end{array}$ \\
\hline $\begin{array}{l}\text { Country } \\
\text { population }\end{array}$ & $\begin{array}{l}-.140 \\
(.128)\end{array}$ & $\begin{array}{c}3.576 \\
(5.285)\end{array}$ & $\begin{array}{l}10.50 * * * \\
(2.652)\end{array}$ & $\begin{array}{c}.863 \\
(2.569)\end{array}$ & $\begin{array}{l}7.848 * * \\
(3.467)\end{array}$ \\
\hline GDPPC & $\begin{array}{l}-.015 \\
(.038)\end{array}$ & $\begin{array}{l}-.668 \\
(.511)\end{array}$ & $\begin{array}{c}-6.622 * * * \\
(1.036)\end{array}$ & $\begin{array}{l}-.120 \\
(.147)\end{array}$ & $\begin{array}{l}-.177 \\
(.446)\end{array}$ \\
\hline $\begin{array}{l}\text { UCDP rebel } \\
\text { Group } \\
\text { Group size }\end{array}$ & $\begin{array}{c}1.595 * * * \\
(.557) \\
.888 * * * \\
(.316)\end{array}$ & & & & \\
\hline $\begin{array}{l}\text { Religious } \\
\text { Group } \\
\text { Holds } \\
\text { Territory } \\
\text { State- } \\
\text { sponsored }\end{array}$ & $\begin{array}{c}.049 \\
(.373) \\
1.109 \\
(.741) \\
.246 \\
(.646)\end{array}$ & & & & \\
\hline Constant & $\begin{array}{c}.106 \\
(1.360)\end{array}$ & $\begin{array}{l}-43.092 \\
(29.06)\end{array}$ & $\begin{array}{l}-11.201 \\
(8.776)\end{array}$ & $\begin{array}{l}-8.980 \\
(25.81)\end{array}$ & $\begin{array}{c}-91.80 * * * \\
(22.35)\end{array}$ \\
\hline $\begin{array}{l}\text { Group fixed effects? } \\
\text { AR(1) disturbances? }\end{array}$ & $\begin{array}{l}\text { No } \\
\text { No }\end{array}$ & $\begin{array}{l}\text { Yes } \\
\text { Yes }\end{array}$ & $\begin{array}{l}\text { Yes } \\
\text { Yes }\end{array}$ & $\begin{array}{l}\text { Yes } \\
\text { Yes }\end{array}$ & $\begin{array}{l}\text { Yes } \\
\text { Yes }\end{array}$ \\
\hline $\begin{array}{l}\text { Observations } \\
\text { (groups) }\end{array}$ & $\begin{array}{l}4,911 \\
(442)\end{array}$ & $\begin{array}{l}1,662 \\
(274)\end{array}$ & $\begin{array}{l}4,469 \\
(390)\end{array}$ & $\begin{array}{l}4,469 \\
(390)\end{array}$ & $\begin{array}{l}1,905 \\
(279)\end{array}$ \\
\hline
\end{tabular}

Standard errors are shown in parentheses. In Model 6, standard errors are clustered by terrorist group. $* \mathrm{p}<10, * * \mathrm{p}<.05, * * * \mathrm{p}<.01$ 
Figure 1. Graph of interaction results from Table 2, Model 4

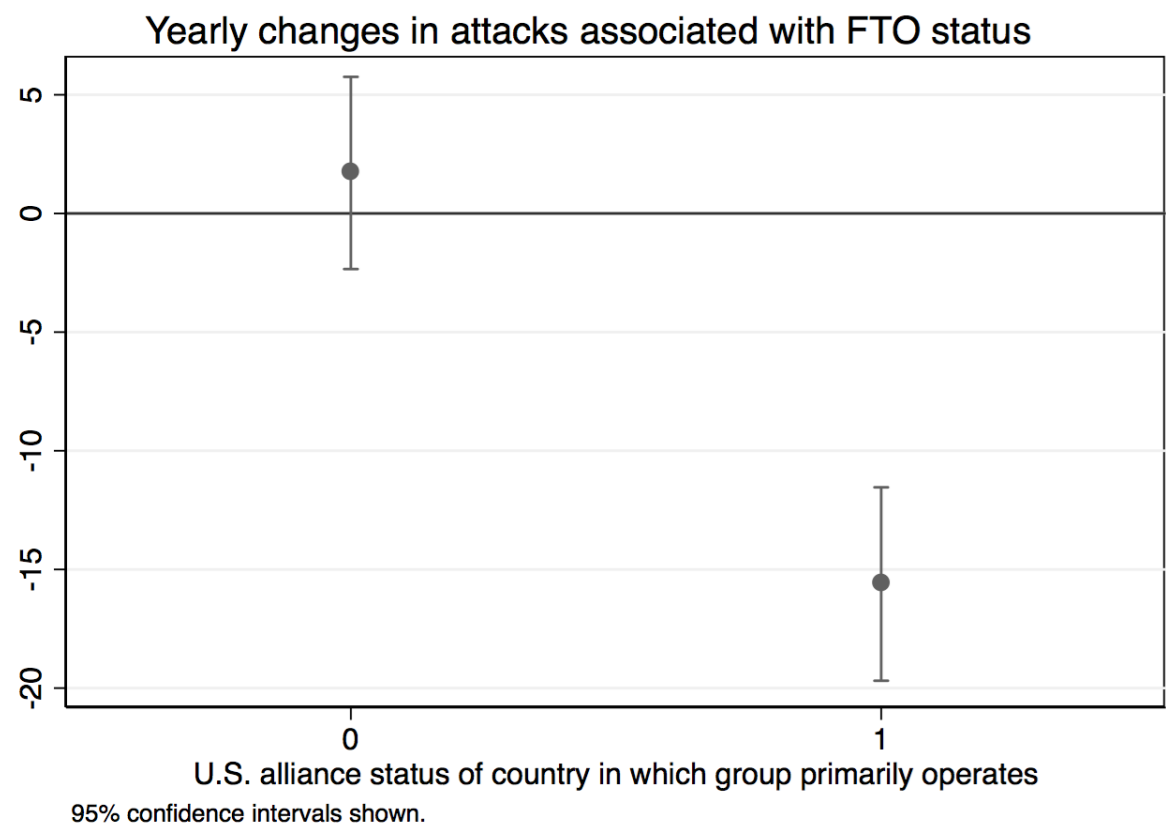

Figure 2. Graph of interaction results from Table 2, Model 5

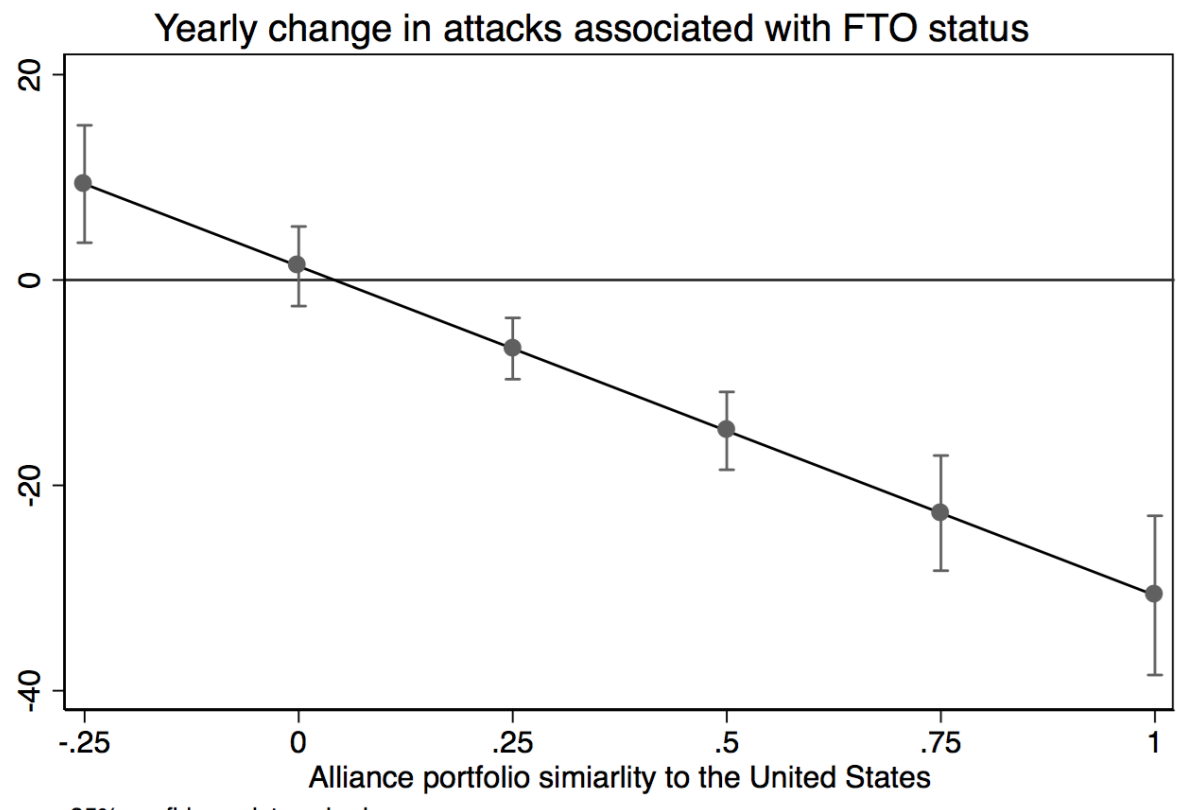

$95 \%$ confidence intervals shown. 


\section{References}

Al Jazeera (2017) India Welcomes US Blacklisting of Hizbul Mujahideen. Al Jazeera. August 18, 2017.

Allison, Graham (1971) Essence of Decision: Explaining the Cuban Missile Crisis. New York: Little Brown.

Argullas, Carolyn O. (2018) "ISIS-Philippines" listed as foreign terrorist organization but is there an "ISIS-Philippines"? MindaNews. March 2, 2018.

Asal, Victor, and R. Karl Rethemeyer. 2008. "The nature of the beast: Organizational structures and the lethality of terrorist attacks." The Journal of Politics 70 (2): 437-449.

Asal, Victor, Marcus Schulzke, and Amy Pate. 2017. "Why do some organizations kill while others do not: An examination of Middle Eastern organizations." Foreign Policy Analysis 13(1): 811-831.

Baltagi, Badi H., \& Wu, Ping X. (1999). Unequally spaced panel data regressions with AR (1) disturbances. Econometric Theory, 15(6), 814-823.

Bantekis, Ilias (2003) The international law of terrorist financing. The American Journal of International Law 97 (2): 315-333.

Bapat, Navin A. (2007) The internationalization of terrorist campaigns. Conflict Management and Peace Science 24 (4), 265-280.

Bapat, Navin A., Luis De la Calle, Kaisa Hinkkainen, and Elena McLean (2016) Economic sanctions, transnational terrorism, and the incentive to misrepresent. Journal of Politics 78 (1): 249-264.

Beck, Colin J., and Emily Miner (2013) Who gets designated a terrorist and why? Social forces 91 (3): 837-872.

Becker, Michael (2017) Why violence abates: Imposed and elective declines in terrorism attacks. Terrorism and Political Violence 29 (2): 215-235.

Berman, Ely (2009) Radical, Religious, and Violent: The New Economics of Terrorism. Cambridge: MIT Press.

Bueno de Mesquita, Bruce. (1975). Measuring systemic polarity. Journal of Conflict Resolution, 19(2), 187-216.

Byman, Daniel (2006). Remaking alliances for the war on terrorism. Journal of Strategic Studies, 29(5), 767-811. 
Carter, David B (2012) A blessing or a curse? State support for terrorist groups. International Organization 66 (1): 129-151.

Center for Security Studies (2014) Kidnapping for ransom as a source of terrorism funding. CSS Analyses in Security Studies No. 141. October.

Chenoweth, Erica. (2010) Democratic competition and terrorist activity. The Journal of Politics 72 (1), 16-30.

Clarke, Colin P. (2015) Terrorism, Inc.: The Financing of Terrorism, Insurgency, and Irregular Warfare: The Financing of Terrorism, Insurgency, and Irregular Warfare. Santa Barbara, CA: ABC-CLIO.

Conde, Carlos H. (2002) U.S. Declares Open Season vs CPP/NPA: Worsening of Abuses Against Civil Liberties Seen. Bulatlat.com. Volume 2, Number 27. August 11-17, 2002.

Conrad, Justin, and James Igoe Walsh (2014) International cooperation, spoiling, and transnational terrorism. International Interactions 40 (4): 453-476.

Coppedge, Michael, John Gerring, Staffan I. Lindberg, Svend-Erik Skaaning, Jan Teorell, David Altman, Michael Bernhard, M. Steven Fish, Adam Glynn, Allen Hicken, Carl Henrik Knutsen, Kyle Marquardt, Kelly McMann, Farhad Miri, Pamela Paxton, Daniel Pemstein, Jeffrey Staton, Eitan Tzelgov, Yi-ting Wang, and Brigitte Zimmerman. 2016. "V-Dem Country-Year Dataset v6.2." Varieties of Democracy (V-Dem) Project.

Crenshaw, Martha (1981) The causes of terrorism. Comparative politics 13 (4): 379-399.

Crenshaw, Martha (1987) Theories of terrorism: Instrumental and organizational approaches. Journal of Strategic Studies 10 (4): 13-31.

Cronin, Audrey Kurth (2003) The "FTO List" and Congress: Sanctioning foreign terrorist organizations. Congressional Research Service report. Oct. 21.

Ilbiz, Ethem, \& Curtis, Benjamin L. (2015). Trendsetters, trend followers, and individual players: Obtaining global counterterror actor types from proscribed terror lists. Studies in Conflict \& Terrorism, 38(1), 39-61.

De Young, Karen (2012) “Officials Split Over Haqqani Network.” The Washington Post. Sept. 1.

Drezner, Daniel W. (1999) The Sanctions Paradox: Economic Statecraft and International Relations. Cambridge: Cambridge University Press.

Efrat, Asif (2015). Do human rights violations hinder counterterrorism cooperation? Evidence from the FBI's deployment abroad. The Review of International Organizations, 10(3), 329-349. 
Enders, Walter, and Todd Sandler (1993) The effectiveness of antiterrorism policies: A vector-autoregression-intervention analysis. American Political Science Review 87 (4): 829-844.

Enders, Walter, and Todd Sandler (2012) The Political Economy of Terrorism. Cambridge: Cambridge University Press.

Financial Action Task Force (2014) FATF 2013-2014 Annual Report. Paris: FATF/OECD.

Financial Action Task Force (2015) Improving Global AML/CFT Compliance: on-going process - 26 June.

Foust, Joshua (2012) The U.S. finally blacklists an Afghan terrorist group. The Atlantic. Sept. 15.

Freeman, Michael (2011) The sources of terrorism financing: Theory and typology. Studies in Conflict and Terrorism 34 (6): 461-475.

Forbes, Mark. (2008) JI declared an illegal network. Sydney Morning Herald. April 22.

Freedman, Benjamin (2010). Officially blacklisted extremist/terrorist (support) organizations: A comparison of lists from six countries and two international organizations. Perspectives on Terrorism 4(2), 46-52.

Gaibulloev, Khusrav, and Todd Sandler (2014) An empirical analysis of alternative ways that terrorist groups end. Public Choice 160 (1-2): 25-44.

Gilmore, William C. (2011) Dirty Money: The Evolution of International Measures to Counter Money Laundering and the Financing of Terrorism. Strasbourg: Council of Europe Publishing.

Häge, Frank M. (2011): Choice or Circumstance? Adjusting Measures of Foreign Policy Similarity for Chance Agreement. Political Analysis 19, 3: 287-305.

Horgan, John, and Max Taylor (1999) Playing the "green card" - Financing the Provisional IRA: Part 1. Terrorism and Political Violence 11 (2): 1-38.

Horgan, John, and Kurt Braddock (2010) Rehabilitating the terrorists? Challenges in assessing the effectiveness of de-radicalization programs. Terrorism and Political Violence 22: $267-291$.

Jarvis, Lee, and Tim Legrand (2018) The Proscription or Listing of Terrorist Organizations: Understanding, Assessment, and International Comparisons. Terrorism and Political

Violence 30 (2): 199-215. 
Johnston, Patrick B. (2012) Does decapitation work? Assessing the effectiveness of leadership targeting in counterinsurgency campaigns. International Security 36 (4):47-79.

Jones, Seth G., and Martin C. Libicki (2008) How Terrorist Groups End: Lessons For Countering al-Qa'ida. Santa Monica: RAND.

Jordan, Jenna (2014) Attacking the leader, missing the mark: Why terrorist groups survive decapitation strikes. International Security 38 (4):7-38.

Jorisch, Avi (2009) Tainted Money: Are We Losing the War on Money Laundering and Terrorism Finance? Washington, D.C.: Red Cell.

Kearns, Erin M., Conlon, Brendan, \& Young, Joseph K. (2014). Lying about terrorism. Studies in Conflict \& Terrorism, 37 (5), 422-439.

Kessler, Glenn (2014) Boko Haram: Inside the State Department debate over the "terrorist" label. Washington Post. May 19.

Leeds, Brett Ashley, Jeffrey M. Ritter, Sara McLaughlin Mitchell, Andrew G. Long (2002) Alliance Treaty Obligations and Provisions. International Interactions 28 (3): 237-260.

Lee, Chia-yi. (2016). Terrorism, counterterrorism aid, and foreign direct investment. Foreign Policy Analysis, 13(1), 168-187.

Levenotoğlu, Bahar, \& Tarar, Ahmer. (2005). Prenegotiation public commitment in domestic and international bargaining. American Political Science Review, 99(3), 419-433.

Levitt, Matthew A. (2002) The political economy of Middle East terrorism. Middle East Review of International Affairs 6 (4): 49-65.

Los Angeles Times (2000) 18 accused of cigarette smuggling to fund Hezbollah. July 22. http://articles.latimes.com/2000/jul/22/news/mn-57451

Marinov, Nikolay, \& Nili, Shmuel. (2015). Sanctions and democracy. International Interactions, 41(4), 765-778.

Mattes, Michaela, \& Vonnahme, Greg. (2010). Contracting for Peace: Do Nonaggression Pacts Reduce Conflict?. The Journal of Politics, 72 (4), 925-938.

Moghadam, Assaf (2017) Nexus of Global Jihad: Understanding Cooperation Among Terrorist Actors. Columbia University Press.

Moran, Lee (2014) British student tried to smuggle $\$ 26 \mathrm{G}$ in her underwear to fund terrorism in Syria: prosecutors. New York Daily News. Jan. 24.

Neumann, Peter R. 2017. Don't Follow the Money: The Problem with the War on Terrorist Financing. Foreign Affairs July/August. 
Neumann, Peter R. 2017. “Can Bankers Fight Terrorism?” (Forum/response to critics.) Foreign Affairs November/December.

Pascoe, Henry. B. (2016). United Nations conventions for the suppression of transnational terrorism and international security cooperation. Doctoral dissertation. University of Texas at Austin.

Phillips, Brian J. (2015) What is a Terrorist Group? Conceptual Issues and Empirical Implications. Terrorism and Political Violence 27 (2): 225-242.

Piazza, James A. (2008) Incubators of terror: Do failed and failing states promote transnational terrorism? International Studies Quarterly 52 (3): 469-488.

Piazza, James A. (2009) Is Islamist terrorism more dangerous? An empirical study of group ideology, organization, and goal structure. Terrorism and Political Violence 21(1): 62-88.

Piazza, James A. (2011) Poverty, minority economic discrimination, and domestic terrorism. Journal of Peace Research 48 (3): 339-353.

Plumper, Thomas, \& Neumayer, Eric. (2010) The friend of my enemy is my enemy: International alliances and international terrorism. European Journal of Political Research, 49(1), 75-96.

Price, Bryan C. (2012) Targeting top terrorists: How leadership decapitation contributes to counterterrorism. International Security 36 (4):9-46.

Ramos, Ana (2005) Spain: Part I: Counter-terrorism in Spain - an overview, pp. 123-131 in Europe Confronts Terrorism (Karin von Hippel, ed.). New York: Palgrave Macmillan.

Rekhi, Shefali. 2002. "U.S. may label J.I. as 'terrorist."” The Straits Times (Singapore). Sept. 25.

Reuters (2012). “Egyptian 'terrorist' group member was no threat: U.S.” June 26.

Rosendorff, B. Peter, \& Sandler, Todd (2004). Too much of a good thing? The proactive response dilemma. Journal of Conflict Resolution, 48(5), 657-671.

Roy Chaudhury, Dipanjan (2017) US designates Hizbul Mujahideen as foreign terrorist group. Economic Times (India). August 17, 2017.

Schwartz, Aaron L. (2014). National Security and the Protection of Constitutional Liberties: How the Foreign Terrorist Organization List Satisfies Procedural Due Process. Penn State Journal of Law and International Affairs 3 (1): 292-323.

Shapiro, Jacob N. (2013) The Terrorist's Dilemma: Managing Violent Covert Organizations. Princeton, N.J.: Princeton University Press. 
Shapiro, Jacob N., and David A. Siegel (2007) Underfunding in terrorist organizations. International Studies Quarterly 51 (2): 405-429.

Signorino, Curtis S., and Jeffrey M. Ritter (1999) Tau-b or not tau-b: measuring the similarity of foreign policy positions. International Studies Quarterly 43 (1): 115-144.

Teorell, Jan, Nicholas Charron, Stefan Dahlberg, Sören Holmberg, Bo Rothstein, Petrus Sundin \& Richard Svensson (2018) The Quality of Government Dataset, version Jan18. University of Gothenburg: The Quality of Government Institute, http://www.qog.pol.gu.se.

Tominaga, Yasutaka (2018) Killing Two Birds with One Stone? Examining the Diffusion Effect of Militant Leadership Decapitation. International Studies Quarterly 54-68.

Tremlett, Giles (2001) US offers to spy on ETA for Spain. The Guardian. June 15.

Tilly, Charles (2004) Terror, Terrorism, Terrorist. Sociological Theory 22 (1): 5-13.

UCDP Actor Dataset 2.2-2015, Uppsala Conflict Data Program, www.ucdp.uu.se, Uppsala University.

U.S. Department of State (2010) Chapter 2. Country reports: East Asia and Pacific overview, in Country Reports on Terrorism 2009. Washington, D.C.

U.S. Department of the Treasury (2015) Terrorist Assets Report: Calendar Year 2014 Twenty-third Annual Report to the Congress on Assets in the United States Relating to Terrorist Countries and International Terrorism Program Designees. Washington, D.C.

U.S. Government Accountability Office (2015) COMBATING TERRORISM: Foreign Terrorist Organization Designation Process and U.S. Agency Enforcement Actions. Washington, D.C.

Van Linschoten, Alex Strick, and Felix Kuehn. 2012. “A Pointless Blacklisting.” The International Herald Tribune. Sept. 13.

Vick, Karl (2007) Al-Qaeda's hand in Istanbul plot: Turks met with Bin Laden. Washington Post. Feb. 13.

Walsh, James I. (2006) Intelligence-sharing in the European Union: Institutions are not enough. Journal of Common Market Studies 44 (3): 625-643.

Weiser, Benjamin. (2009) S.I. Man Gets Prison Term for Aid to Hezbollah TV. New York Times. April 23.

Young, Joseph K. (2012) Naughty or nice? The politics of the FTO list. Political Violence at a Glance. Oct. 8. 


\section{Notes}

${ }^{1}$ http://www.state.gov/j/ct/rls/other/des/123085.htm

${ }^{1}$ Some research looks at how sanctions against states affect terrorist groups (Bapat et al. 2016). This is a different topic than sanctions against terrorist groups.

${ }^{3}$ The full list is available here: http://www.state.gov/j/ct/rls/other/des/123085.htm

${ }^{4}$ Differences across group types are also argued to occur because idiosyncratic political factors play a role in the designation of terrorist groups in each country or entity (Beck and Miner 2013, Jarvis and Legrand 2018). This is discussed more below.

${ }^{5}$ The State Department defines terrorism as "premeditated, politically motivated violence perpetrated against non-combatant targets by subnational groups or clandestine agents." See Title 22 of the U.S. Code, Section $2656 f(d)$. A "terrorist group" is basically any subnational political organization that uses terrorism (Phillips 2015, 231). This is a broad notion of terrorist groups, but it is used by many scholars (e.g., Jones and Libicki 2008), and is consistent with the State Department's understanding of the concept. For more on the concepts of terrorism and terrorist, and criticisms of the State Department's terminology, see Tilly (2004).

${ }^{6} \mathrm{http}: / / \mathrm{www}$. state.gov/j/ct/rls/other/des/123085.htm. Italics in original.

${ }^{7}$ Interview with Jason Blazakis, Director of the Office of Counterterrorism Finance and Designations, Bureau of Counterterrorism, at the Department of State, Washington D.C., March 18, 2015.

${ }^{8}$ The six-step process to designate groups is described in a report by the Government Accountability Office (2015).

${ }^{9}$ Initially, designations lasted only two years, but this was soon increased to five years. 
${ }^{10}$ This is relevant from a research design perspective because it further suggests FTO status is not simply a function of group attacks.

11 Terrorist groups also often cease to exist as organizations or stop using terrorism altogether, which is the subject of many studies (Carter, 2012; Jones and Libicki, 2008). However, relatively few of the FTOs no longer exist, so analysis of group failure as a possible result of designation is difficult due to little variation on the dependent variable. 12 The Taliban was sanctioned via Executive Order, but is not on the FTO list. Otherwise, there are very few individuals or groups not already covered by the FTO list. Interview with a former U.S. Department of the Treasury official, Washington D.C., March 17, 2015. ${ }^{13}$ In 2012, a member of Egyptian FTO al Gama legally entered the United States for meetings in Washington. This caused a controversy regarding whether he received a waiver or if his admittance was a mistake (Reuters 2012). Regardless, the case shows that members of FTOs seek to enter the United States to lobby for their groups. The number of visa denials mentioned above suggests that most FTO "lobbyists" are not successful at legally entering.

${ }^{14}$ One means to reduce public concern is keeping cooperation, or at least negotiations, secret (Leventoglu and Tarar 2005).

${ }^{15}$ Shapiro and Siegel (2007) argue that a "critical threshold" of funding restrictions must be reached for them to be effective. Perhaps in the case of FTO sanctions, that threshold is only met when the United States can effectively partner with group's country.

${ }^{16}$ Interview with Jason Blazakis, Director of the Office of Counterterrorism Finance and Designations, Bureau of Counterterrorism, at the Department of State, Washington D.C., March 18, 2015. 
17 These years are based on the availability of the data. A robustness check is reported on the 1997-2006 sample, and primary results hold. However, using data further back in time is helpful because many of the groups started before 1997, so truncating the data loses important information on these groups. For example, it is interesting to analyze all of Hezbollah's existence (as far back as 1982), to observe how the group changed with time, including when it went from being a non-FTO to an FTO.

${ }^{18}$ All groups on the FTO list during the years of the Jones and Libicki data are included in my data, even though some groups might not be immediately apparent. One issue is slight changes in names, such as the FTO Islamic Jihad Union, which is in Jones and Libicki as the Islamic Jihad Group.

${ }^{19}$ As noted, group longevity could be a dependent variable, but few FTOs have ceased to exist or given up terrorism, so there is insufficient variation for meaningful analysis.

${ }^{20}$ If a model is estimated where the dependent variable is FTO status, neither a group's lagged attacks nor change in attacks are statistically significant, consistent with previous work (Beck and Milner 2013). This should reduce concerns about reverse causality. ${ }^{21}$ FTOs that are coded as operating primarily in a U.S. ally state, according to ATOP, during at least some years of the study are those in Chile, Colombia, Greece, Japan, Pakistan, Peru, the Philippines, Spain, Turkey, the United Kingdom, or Uzbekistan. ${ }^{22}$ I exclude non-aggression and neutrality pacts because they imply a lower level of security cooperation (Mattes and Vonnahme 2010).

${ }^{23}$ It is also weighted by the distance between countries, as well as the type of alliance.

${ }^{24}$ If the mean pre-2001 value is inputted for the post-2000 years, results are similar. 
${ }^{25}$ If the size variable is broken down into its size categories, the two largest categories are positively associated with attack changes, relative to the smallest category.

${ }^{26}$ If a variable is included measuring the number of terrorist groups in the country-year, it is statistically significant and positively signed. However, other results are substantively unchanged. If the variable is included in other models, it is never statistically significant. 